\title{
ACIDITY OF SNOW AND ITS REDUCTION BY ALKALINE AEROSOLS
}

by

\section{Motol KUMAI}

Cold Regions Research and Engineering Laboratory, Hanover NH 03755, USA

\section{ABSTRACT}

Snow crystals scavenge aerosols in the atmosphere during the processes of growth and precipitation. Several kinds of flyash are found in acid snow by scanning electron microscope examination. Flyash particles from coalfired electric power plants in Fairbanks, Alaska, were found to be spherical or irregular in shape with a 0.2 to $50 \mu \mathrm{m}$ diameter, and were rich in calcium, silicon, aluminum and iron. The $\mathrm{pH}$ of 35 snow samples in Fairbanks ranged from 5.60 to 7.48 . The acid snow was changed to alkaline snow by dry fallout of calcium-rich flyash from the electric power plants, which were using calcium-rich Alaskan coal.

Flyash particles from three oil fired heating plants in Hanover, New Hampshire, were spherical and 10 to $80 \mu \mathrm{m}$ in diameter, with gas escape holes, and were always sulfur rich. The $\mathrm{pH}$ values of fresh snow from 44 snowfalls were measured to range from pH 3.96 to 5.45 in Hanover. The mean hydrogen ion concentration was calculated to be $10^{-4.48} \mathrm{~mol} / \mathrm{L}$ for 22 snowfalls in $1980-84$, and $10^{-4.61} \mathrm{~mol} / \mathrm{L}$ for 22 snowfalls in 1972-73.

\section{INTRODUCTION}

Acid precipitation has been studied in various locations by many workers (Campbell and others 1978; Munger 1982; Winkler 1983; and Barrie and others 1984). The mean acidity of surface snow and deep ice on the ice cap in Ellesmere Island $\left(81^{\circ} \mathrm{N}\right.$ and $\left.73^{\circ} \mathrm{W}\right)$ was measured to be $\mathrm{pH} 5.48$ for the Holocene and $\mathrm{pH} 5.23$ for 1954-80 (Koerner and Fisher 1982). Precipitation with relatively high acidity was reported in the northeastern United States by Stensland and Semonin (1982). The concentrations of cloud condensation nuclei in the plumes from coal fired electric power plants were found to be a few times greater than those in the ambient air (Hobbs and others 1980). Flyash particles from coal fired electric power plants in the Tennessee Valley Authority system were of glass, mullite-quartz and magnetic spinel (Hulett and others 1980). Aerosols such as soil particles and solid combustion by-products are as important to a full interpretation of the distribution of acid precipitation as the anthropogenically produced emissions.

This paper presents the results of an investigation of (1) the scanning electron microscope examinations of flyash in fresh snow, from coal fired electric power plants and oil fired heating plants; (2) simultaneous measurements of $\mathrm{pH}$ and electrical conductivity of fresh snow and snow cover with flyash by dry fallout; (3) and the reduction of acidity of snow by precipitated alkaline flyash.

\section{MATERIALS AND METHODS}

The acidities of snow in Fairbanks, Alaska, and Hanover, New Hampshire, were measured with a combination electrode (Thomas glass electrode with Calomel reference electrode) using an Orion Research Ionanalyzer, which is calibrated with buffer solutions of $\mathrm{pH} 4.01$ and $\mathrm{pH} 7.00$. Electrolytic conductivities $\left(\mu \mathrm{S} \mathrm{m}^{-1}\right)$ of the snow meltwater were measured with a conductance (model RCM 1581, Thomas Co) bridge model at room temperature $\left(25^{\circ} \mathrm{C}\right)$.

Flyash particles from coal fired electric power plants in Alaska and oil fired heating plants in New
Hampshire were examined by scanning electron microscopy to compare with those in fresh snow. To examine chemical species and concentrations of flyash in fresh snow, $20 \mathrm{~mL}$ of snow meltwater was filtered through $1 \mu \mathrm{m}$ polycarbonate membrane filters. The flyash remaining on the filters was coated with gold palladium vapor to a thickness of about $10 \mathrm{~mm}$. The characteristics and elemental compositions were examined with a scanning electron microscope (SEM) and energy dispersive X-ray analyzer (EDXA).

\section{FLYASH FROM CHIMNEYS}

Emissions of sulfur dioxide and nitrogen oxide from fossil fuel combustion are believed to be the cause of acid precipitation. Characteristics of coal were examined to compare with those of the flyash. A typical

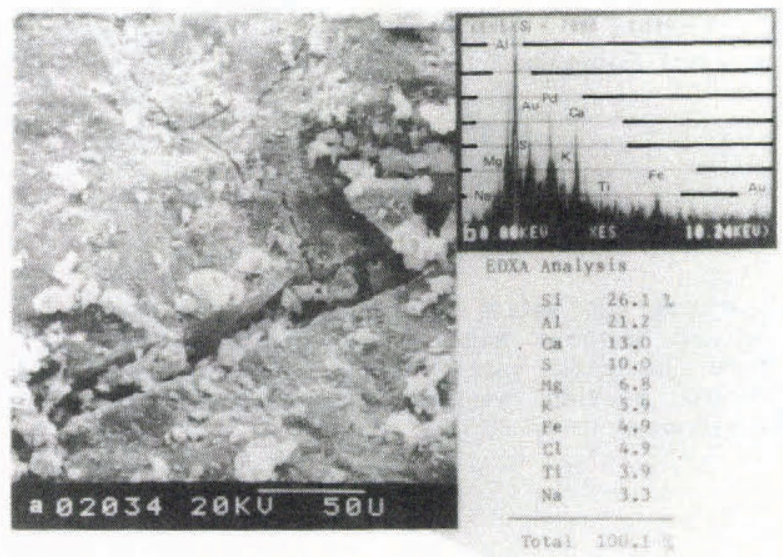

Fig.1. Scanning electron micrograph (SEM) of coal used at electric power plants in Fairbanks, Alaska (a); the elemental composition of the flyash indicates that the coal contains alkali earth metals (b).

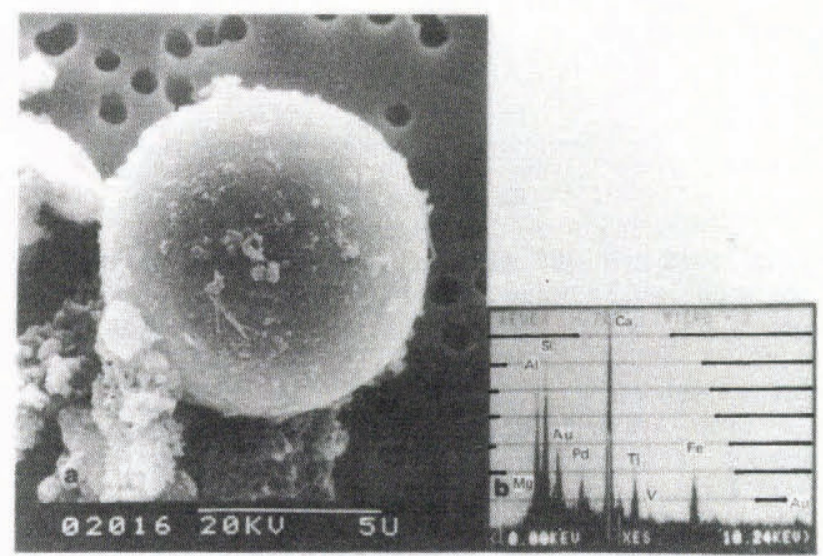

Fig.2. SEM of flyash from coal fired electric power plant in Fairbanks (a); the elemental composition of the flyash indicates that the flyash contains rich calcium (b). 
scanning electron micrograph of Alaskan coal used at coal fired electric power plants in Fairbanks shows minerals and cracks on the surface (Figure la). The elemental compositions of the minerals were found to be alkali earth metals: $\mathrm{Ca} 13.0, \mathrm{Mg} 6.8, \mathrm{~K} 5.9$, and $\mathrm{Na} 3.3 \%$ by weight (Figure 1b). Flyash particles from coal fired electric plants in Fairbanks were irregular and spherical in shape, with 0.2 to $50 \mu \mathrm{m}$ diameters. The elemental compositions of spherical ash were similar to those of irregular ash. When the flyash particles were separated into four kinds ( $\mathrm{Ca}, \mathrm{Si}, \mathrm{Al}$, and $\mathrm{Fe}$ rich) the $\mathrm{Ca}$ rich flyash was found to be the most common. A typical Ca rich flyash (Figure 2a) is $9 \mu \mathrm{m}$ in diameter, and the elemental composition (Figure 2b) is $\mathrm{Ca} 28, \mathrm{Mg} 4, \mathrm{Si} 22$, $\mathrm{Al} 17, \mathrm{Fe} 8$, and $\mathrm{Ti} 7 \%$ by weight. The dry fallout of the alkaline flyash could reduce the acidity of the snow (Stensland and Semonin 1982).

Flyash from oil fired heating plants in Hanover was always composed of $\mathrm{S}$ rich particles 10 to $80 \mu \mathrm{m}$ in diameter. The sulfur contents in the flyash ranged from $30 \%$ to $50 \%$ by weight. A typical scanning electron micrograph of the flyash (Figure 3a) shows a spherical shape with porous structure. The major elemental compositions were $\mathrm{S} 34.9, \mathrm{Si} 8.7$, and $\mathrm{Cl} 7.4 \%$ by weight, and the minor elements $(\mathrm{Na}, \mathrm{Mg}, \mathrm{Al}, \mathrm{K}, \mathrm{Ca}, \mathrm{Ti}, \mathrm{Cr}, \mathrm{Fe}$ $\mathrm{Co}$, and $\mathrm{Cu}$ ) were less than $5 \%$ (Figure $3 \mathrm{~b}$ ). From these

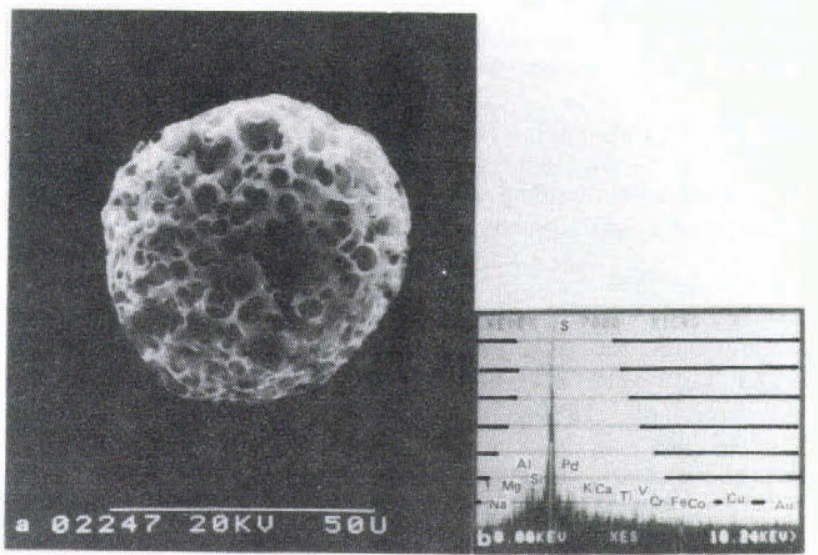

Fig.3. SEM of flyash from oil fired heating plants in Hanover, New Hampshire (a); the elemental composition of the flyash indicates that the flyash contains rich sulfur (b).

measurements, it seems therefore that flyash from oil fired heating plants can be distinguished by elemental composition and morphology from those of coal fired electric power plants.

\section{FLYASH IN FRESH SNOW}

Flyash particles act as freezing nuclei during snow crystal formation in the supercooled clouds. Snow crystals scavenge flyash during the precipitation stage in the atmosphere. Four kinds of flyash ( $\mathrm{Si}, \mathrm{S}, \mathrm{Al}$, and $\mathrm{Fe}$-rich) were found in fresh snow in Hanover, New Hampshire. The flyash particles found in the fresh snow were $73.5 \%$ Si-rich, $19.3 \%$ S-rich, $4.1 \%$ Al-rich, and $3.1 \%$ $\mathrm{Fe}$-rich. Elemental compositions of typical Sirich flyash particle (Figure 4) are $\mathrm{Si} 55, \mathrm{Al} 30, \mathrm{~K} 7, \mathrm{Ti} 3, \mathrm{Fe} 2$, and $\mathrm{Na} 1 \%$ by weight, which indicates a low content of alkaline metals as compared to that in Alaskan coal.

The flyash particles in the fresh snow samples ranged from 0.2 to $35 \mu \mathrm{m}$ in diameter. The density of flyash ( $>1 \mu \mathrm{m}$ diameter) in the snow ranged from 4 to 600 particles $/ \mathrm{mL}$, and the mean density was 392 particles $/ \mathrm{mL}$ for measurements of 9 snowfalls. The variety of the density depends on a variety of meteorological conditions during snow precipitation. The mean flyash density in snow from New Hampshire is about 100 times higher than that of Greenland snow (Kumai 1966). The chemistry of snow in New Hampshire is much more influenced by fossil fuel combustion than Greenland snow.

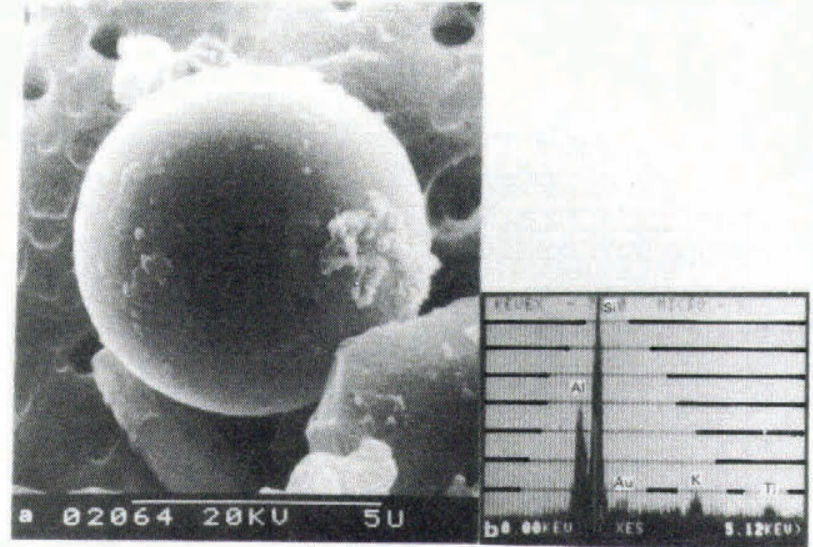

Fig.4. SEM of flyash in fresh snow from Hanover, New Hampshire (a); the elemental composition of the flyash indicates that the flyash contains rich silicon (b).

\section{THE pH AND ELECTRICAL CONDUCTIVITY}

Simultaneous measurement of $\mathrm{pH}$ and electrical conductivity of snow in Fairbanks, Alaska, and Hanover, New Hampshire, were conducted to investigate the characteristics of flyash in snow and the influence of flyash on acid snow.

\section{Snow cover in Fairbanks}

The depth of the snow cover was 30 to $50 \mathrm{~cm}$ in early April 1973 in Fairbanks. Thirty-six snow samples (surface to $5 \mathrm{~cm}$ in depth) were collected in polyethylene bottles near coal fired electric power plants in the city and the rural area. The $\mathrm{pH}$ measurements of snow were carried out at room temperature in April 1973 , and the results were plotted vs. distance from the coal fired electric power plant (Figure 5). The acidity of snow increased with the distance from the powe plant. The maximum acidity of pH $5.60\left(399 \mu \mathrm{S} \mathrm{m} \mathrm{m}^{-1}\right)$ was obtained in snow sampled in a rural area about 20 $\mathrm{km}$ from the plant. The snow melt-water of $\mathrm{pH} 5.60$ corresponds to pure water with dissolved atmospheric carbon dioxide at $0.03 \%$ by weight. However, snow within $1 \mathrm{~km}$ from the power plant was always alkaline

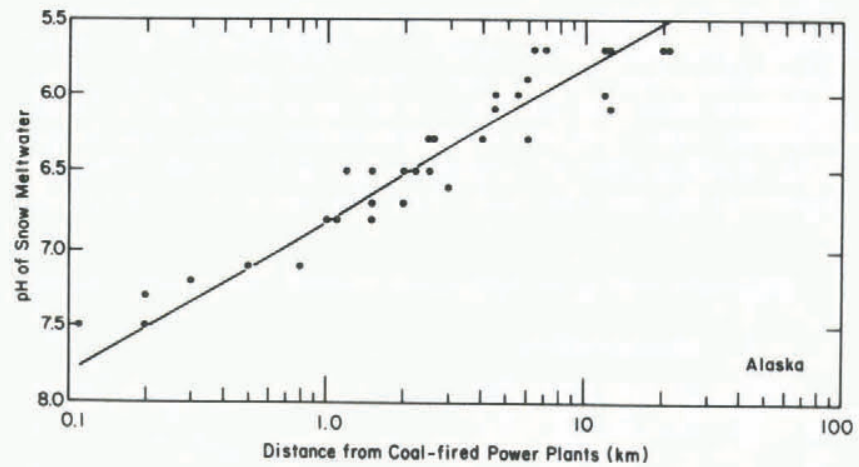

Fig.5. The $\mathrm{pH}$ vs distance of snow from coal fired electric power plant in Fairbanks, Alaska.

due to the dry fallout of alkaline flyash from the Alaskan coal containing alkali earth metals.

Simultaneous measurements were made of $\mathrm{pH}$ and electrical conductivity of 36 snow samples in the city and the rural area, and the results show that the acidity decreased with the electrical conductivity (Figure 6). In Fairbanks, the electrical conductivity was increased with concentration of alkaline ions from the alkaline flyash in the snow. A snow sample near the power plant was pH 7.50 with an electrical conductivity of $4,500 \mu \mathrm{S} \mathrm{m}^{-1}$. The acid snow was changed to alkaline snow by alkaline flyash from the power plant. 


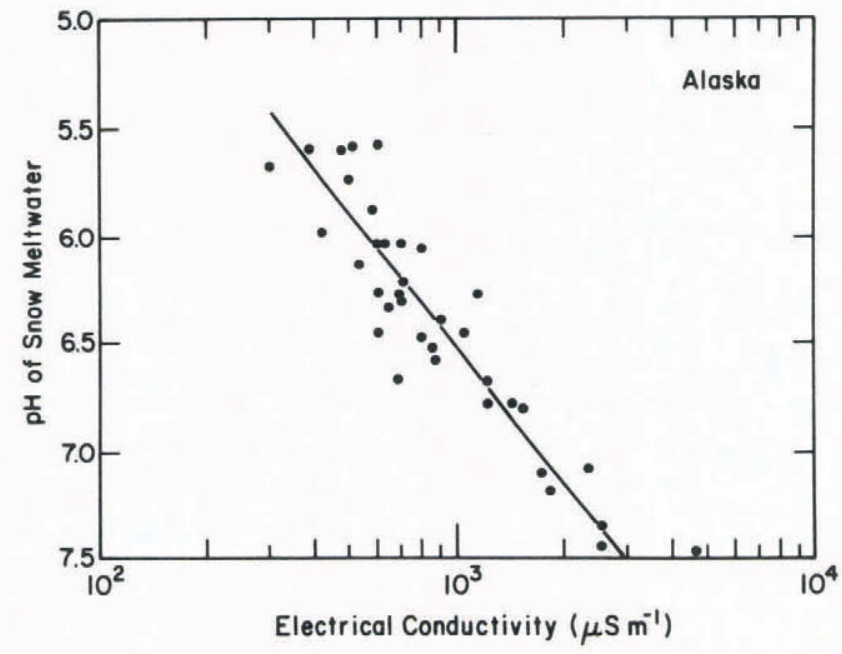

Fig.6. The pH vs electrical conductivity of snow in a rural area and near a coal fired electric power plant in Fairbanks, Alaska.

\section{Snow cover in Hanover}

The depth of the snow cover was 25 to $30 \mathrm{~cm}$ in early February 1984 in Hanover, New Hampshire. Alkaline flyash particles (Figure 2) were not found in the Hanover snow. Snow near oil fired heating plants was covered with dense flyash. The flyash particles were spherical in shape with a porous structure, and the main element was sulfur (Figure 3). The $\mathrm{pH}$ of the snow was plotted vs. distance $(10-500 \mathrm{~m})$ from the oil fired heating plant. The acidity of snow was not changed with distance by sulfur rich flyash from the heating plant. The snow along the roadside was $\mathrm{pH} 7.29$ with an electrical conductivity of $3,000 \mu \mathrm{S} \mathrm{m}^{-1}$ and was apparently influenced by soil and salts spread on the snowy road.

\section{Fresh snow in Hanover}

Measurements of $\mathrm{pH}$ and electrical conductivity of 22 snowfalls $(207 \mathrm{~mm}$ in water equivalent) were conducted during 1972-73, and compared with those of 22 snowfalls (206 $\mathrm{mm}$ in water equivalent) during the 1980-84 in Hanover. The amount of snow (207 mm) is about one-third the annual precipitation in New Hampshire. The result shows that the acidities of snow increased with the electrical conductivities (Figure 7). In Hanover, the electrical conductivities were increased with concentration of hydrogen ion in the snow. The $\mathrm{pH}$ trend shown by the solid line for snow in 1980-84 is

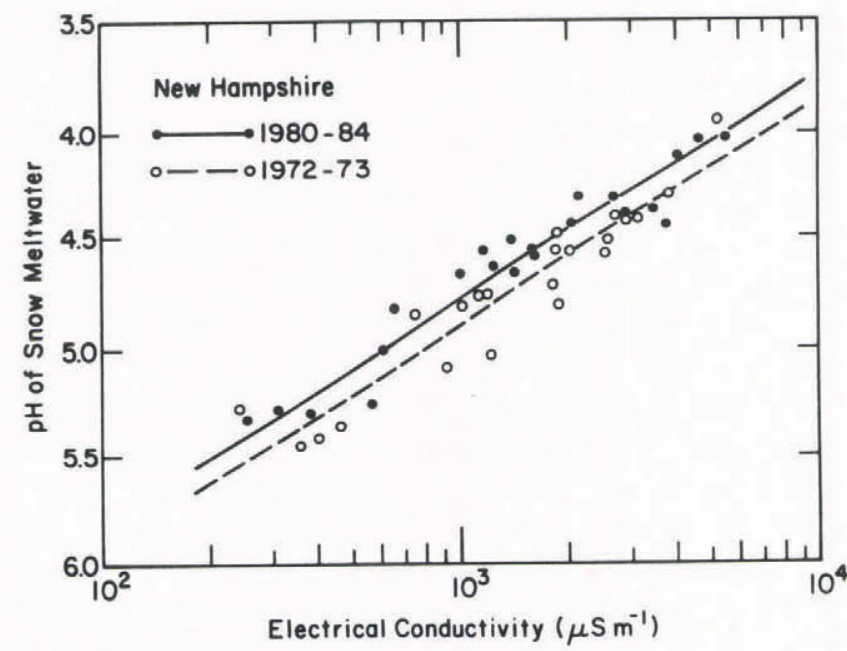

Fig.7. The pH vs electrical conductivity of snow collected during $1972-73$ and $1980-84$ in Hanover, New Hampshire. higher than that shown by broken line for snow in 1972-73. This indicates that the acidities of snow in 1980-84 were higher than those of snow in 1972-73. In this period, coal consumption also increased in the United States. The mean hydrogen ion concentration of 22 snowfalls in $1980-84$ was calculated to be $10^{-4.48}$ $\mathrm{mol} / \mathrm{L}$, and that of 22 snowfalls in $1972-73$ was $10^{-4.61}$ $\mathrm{mol} / \mathrm{L}$.

The acidities of snow ranged from $\mathrm{pH} 5.45$ to $\mathrm{pH}$ 3.96 , and the electrical conductivities ranged from 240 to $5,500 \mu \mathrm{S} \mathrm{m} \mathrm{m}^{-1}$. Each snowfall has different values of $\mathrm{pH}$ and electrical conductivity due to the different meteorological conditions such as air-mass source region, wind direction, amount of precipitation, and snow crystal habits. Relatively high acidity of snow was obtained during south winds and lower precipitation rates, and when rimed snow crystals were present. Air masses from the south generally contained higher concentrations of flyash than those from the north in New Hampshire. Rimed snow crystals contained more acid condensation nuclei than those of non-rimed snow crystals. Condensation nuclei are mainly combustion by-products, and are acid nuclei. Relatively low acid snow was obtained from north wind, large precipitation, and non-rimed snow crystals.

In conclusion, it was found that the acidity of snow was reduced by alkaline aerosols, soil minerals, and flyash containing alkali earth metals from coal fired electric power plants in Fairbanks, Alaska.

\section{ACKNOWLEDGEMENTS}

This work was supported by Corps of Engineers environmental funding at the Cold Regions Research and Engineering Laboratory, Hanover, New Hampshire.

\section{REFERENCES}

Barrie L A, Vet R J 1984 The concentration and deposition of acidity major ions and trace metals in the snowpack of the Eastern Canadian shield during winter of 1980/81. Atmospheric Environment 18(7): 1459-1469

Campbell J A, Laul J C, Neilson K K, Smith R D 1978 Separation and chemical characterization of finely sized flyash particles. Analytical Chemistry 50(8): 1032-1040

Hobbs P V, Smith J L, Radke L F 1980 Cloud-active nuclei from coal-fired electric power plants and their interactions with cloud. Journal of Applied Meteorology 19: $439-451$

Hulett L D, Weinberger A J, Northcutt K J, Ferguson M 1980 Chemical species in flyash from coal-burning power plants. Science 210: 1356-1358

Koener R M, Fisher D 1982 Acid snow in the Canadian High Arctic. Nature 295: 137-140

Kumai M 1966 Microspherules in snow and ice-fog crystals. Journal of Geophysical Research 71: 3397-3404

Munger J W 1982 Chemistry of atmospheric precipitation in the north-central United States: influence of sulfate, nitrate, ammonia and calcereous soil particulates. Atmospheric Enviroment 16(7): 1633-1645

Stensland G J, Semonin R G 1982 Another interpretation of the $\mathrm{pH}$ trend in the United States. Bulletin of the American Meteorological Society 63: $1277-1284$

Winkler P 1983 Acidity of aerosol particles and of precipitation in the North Polar region and over the Atlantic. Tellus 35B: 25-30 